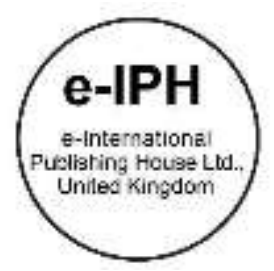

\title{
Bending Behavior of Splice Connection for Mengkulang Glued Laminated Timber Beam
}

\author{
Rohana Hassan ${ }^{1}$, Tengku Anita Raja Husin², Nor Jihan Abd Malek², Mohd Sapuan Salit ${ }^{3}$ \\ ${ }^{1}$ Fellow Researcher, Institute for Infrastructure Engineering and Sustainable Management (IIESM), Universiti Teknologi MARA, 40450 \\ Shah Alam, Selangor, Malaysia \\ ${ }^{2}$ SEGi University, No 9, Jalan Teknologi, Taman Sains Selangor, Kota Damansara, PJU 5, 47810 Petaling Jaya, Selangor Darul \\ Ehsan, Malaysia \\ ${ }^{3}$ Laboratory of Biocomposite Technology Institute of Tropical Forestry and Forest Products (INTROP), Universiti Putra Malaysia, \\ 43400 UPM Serdang, Selangor, Malaysia
}

rohan742@uitm.edu.my, anitahussin@segi.edu.my, jihanmalek@segi.edu.my, sapuan@upm.edu.my Tel: +60196963491

\begin{abstract}
This paper presents the experimental bending strength of steel dowelled splice glulam timber made of 'Mengkulang' species. Bending tests were conducted under a four-point bending load. Six (6) glulam specimens with $45 \mathrm{~mm} \times 90 \mathrm{~mm} \times 1800 \mathrm{~mm}$ were loaded. Three (3) specimens were full beams as the control and three (3) splice beams dowelled with grade 8.8; $20 \mathrm{~mm}$ diameter steel rod. The embedded length of the steel dowel was $60 \mathrm{~mm}$ and glued at $2 \mathrm{~mm}$ thickness on both sides. Results show that the bending strength of the glulam control beam performed $74.18 \%$ higher than the splice beams with an increment of $58.26 \%$ displacement.
\end{abstract}

Keywords: Structural material, flexural strength, failure mode, dowelled connection

eISSN: 2398-4287@ 2021. The Authors. Published for AMER ABRA cE-Bs by e-International Publishing House, Ltd., UK. This is an open access article under the CC BYNC-ND license (http://creativecommons.org/licenses/by-nc-nd/4.0/). Peer-review under responsibility of AMER (Association of Malaysian Environment-Behaviour Researchers), ABRA (Association of Behavioural Researchers on Asians/Africans/Arabians) and cE-Bs (Centre for Environment-Behaviour Studies), Faculty of Architecture, Planning \& Surveying, Universiti Teknologi MARA, Malaysia.

DOI: https://doi.org/10.21834/ebpj.v6iSI4.3029

\subsection{Introduction}

Glulam timber is manufactured by glueing several layers of lumber with adhesive. By glueing several layers of lumber, a strong and large cross-section, the structural element can be produced as glulam based on procedures stated in MS 758:2001. The glulam timber is available in straight and curved shapes due to its flexibility (Margarita, 2017). It is undeniable that glulam has enhanced the potential of timber to act as a construction material in construction field. In North America, the engineered wood product represents $5 \%$ of the overall structural wood product demand (Smith et al. 2006).

Glulam timber is stronger because of the glulam laminating process. Laminating enables the defects of timber scattering in the glulam structural member. Glulam is gradually obtaining momentum within the industry; thus, the connection between glulam becoming a serious issue to be discussed. Generally, when the load is applied to structural members, the weakest point will be the connection. One of the common types of connection is glued in rod. Glued in a rod is the steel dowel glued and inserted accordingly to the required embedded length into the glulam with a suitable adhesive.

Bending performance of structural timber beams can be observed based on the physical and mechanical properties of the member. Three main timber quality criteria are dimensional stability (low distortion), bending strength (Modulus of Rupture (MOR)) and stiffness (Modulus of Elasticity (MOE)) (Kliger et al., 1994). According to Moore et al. 2019, the value of bending strength (MOR) for structural

eISSN: 2398-4287C 2021. The Authors. Published for AMER ABRA CE-Bs by e-International Publishing House, Ltd., UK. This is an open access article under the CC BYNC-ND license (http://creativecommons.org/licenses/by-nc-nd/4.0/). Peer-review under responsibility of AMER (Association of Malaysian Environment-Behaviour Researchers), ABRA (Association of Behavioural Researchers on Asians/Africans/Arabians) and cE-Bs (Centre for Environment-Behaviour Studies), Faculty of Architecture, Planning \& Surveying, Universiti Teknologi MARA, Malaysia.

DOI: https://doi.org/10.21834/ebpj.v6iSI4.3029 
timber in Sitka Spruce in United Kingdom can be ranged from 16.7 to $65.4 \mathrm{Mpa}$, which has a direct relationship with MOE but not the density.

\subsection{Glued Laminated Timber}

The usage of glulam timber in Malaysia is minimal due to the lack of available information on glulam timber properties and design among the architects and engineers. The first tall glulam building in Malaysia where load-bearing timbers were used for its structure is located at Johor (Fig. 1). The shortage of research activities in this specific field contributes to this scenario. Thus, the development of up to date codes of practice for architects, engineers, and builder is crucial. Malaysia is one of the primary producers of the world's good quality timbers that are extensively demanded worldwide. However, it is unfortunate that glulam is not much used in Malaysia due to Uniform Building By-Laws 1984. It specified that timber should be avoided in high-risk constructions and could only be used in temporary structures (Ahmad, 2013). In contrast to countries such as United Kingdom, Australia, Japan, and New Zealand have extensively construct commercial and high-rise buildings using glulam.

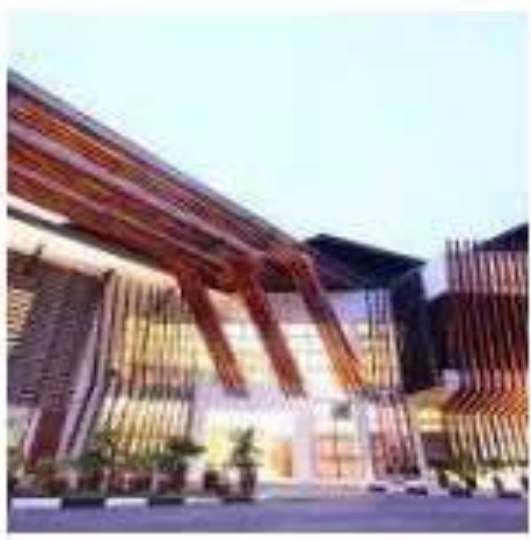

(a)

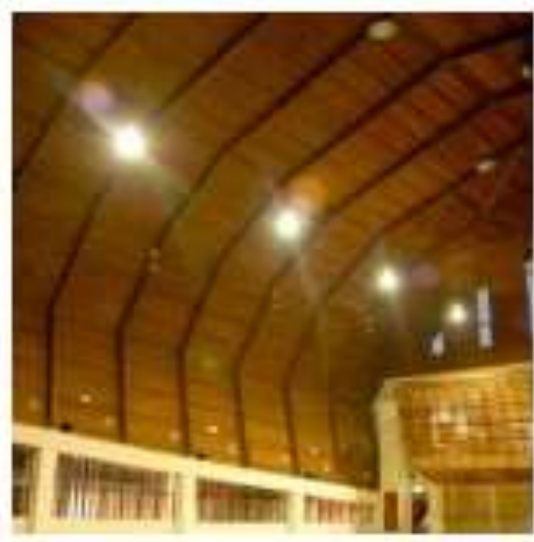

(b)

Fig.1: The Malaysian Timber Industry Board's (MTIB) iconic timber building in Tebrau, Johor Bahru: (a) Front view (b) Internal view (Source: Malaysian Timber Industry Board (MTIB))

Information on Malaysian structural timber species is available in MS 544: Part 2: 2021. Ninety-four (94) species are categorized in strength group (SG) 1 to 7 . The rank of these timbers is by having the strongest structure and highest density in SG1 followed by decreasing strength and density by the increasing SG. Mengkulang (Heritiera s.p) is classified in SG 5. At the same time, the reference for glulam permissible stress design of glued laminated timber is available in MS 544: Part 3: 2001. Due to the suitable properties of Mengkulang to be designed as glulam product and availability in the market; a group of researchers lead by Hassan at Universiti Teknologi MARA, Malaysia, has tested on Mengkulang glulam capabilities such as on the shear block test performance (Malek et al. 2019); pull-out strength of steel rods bonded at five different angles to the grain (Mohamad et al. 2018); comparison of bolt withdrawal capacity (Malek et al. 2016 and 2020) and perpendicular dowel-bearing strength properties without glue line (Malek et al. 2016). The bending strength capacity of the Mengkulang glulam beam has also been tested and reported by Ismail et al. 2020. Their mean bending strength parallel to the grain tested for $(85 \times 90 \times 1710) \mathrm{mm}$ Mengkulang glulam beam is recorded as 81.30 Mpa with load-carrying capacity of $28.26 \mathrm{kN}$. Observation of failure modes on glulam beam bending was found to be brittle (Ismail et al. 2020 and Anshari et al. 2010).

One of the primary structural member design capacity evaluations is the connection between members. Splice joint information is available for Eurocode 5 (EN 1995 -1-1: Design for timber structures). They can be used to connect beams or columns (Robot, 2018). The splice joint contributes to the moment capacity of the connection. Its failure mode is predicted considering the potential brittle plug shear failure of the splice joints, the fasteners' ductile yielding, and the wood failure under compression at the timber interface (Zarnani, 2014).

From a design perspective, failure characteristics of connections in glulam must be recognized and understood as distinct from mechanisms for similar glulam beam timber products. The main purpose of this study was to investigate the performance and the type of failure mode mechanisms obtained for splice connections using commonly steel dowel adopted fastener.

\subsection{Methodology}

A local glulam factory manufactured the Mengkulang glulam based on the manufacturer's specification for wood-based panel products. All pieces of timber prior to the manufacturing process were visually graded for strength properties according to MS1714: 2003. The timber pieces were graded into tropical medium hardwood, structural grade and were dried to moisture content of $8 \%$ to $15 \%$. A total of 
six (6) glulam beams specimens of $45 \mathrm{~mm}$ in width, $90 \mathrm{~mm}$ in depth and $1800 \mathrm{~mm}$ in length were prepared accordance with BS EN 408:2010. Each beam had three laminations with approximately $30 \mathrm{~mm}$ thickness for each layer. The thickness has been designed not to exceed $50 \mathrm{~mm}$ of individual laminations as recommended by Wan Mohamad et al. 2011. Phenol Resorcinol Formaldehyde (PRF) adhesive was used in joining three $30 \mathrm{~mm}$ thick lamination to form the $90 \mathrm{~mm}$ beam depth. PRF is an adhesive approved and used in any climate for indoors and outdoors (Margarita, 2017). All glulam specimens were taken from one production source to ensure the uniformity of testing results. Fig. 2 shows the dimension and preparation of the specimen of the four-point bending load. Table 1 shows the specification of the glulam beam specimens.

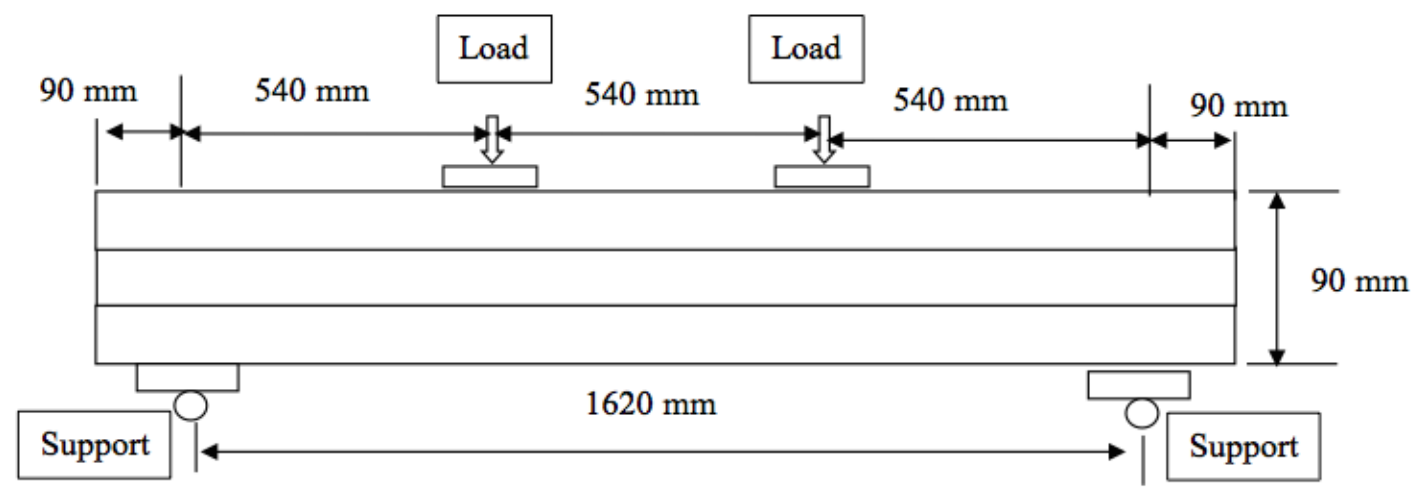

Fig.2: Dimensions and set up the preparation of Mengkulang glulam beam for the four-point bending test.

Two sets of specimens, one categorized as without connectors for the control specimens and the second set, were dowelled at spliced members. The spliced position was precisely at the centre of the whole beam length.

Table 1: Specification of glulam beam specimens

\begin{tabular}{lllllll}
\hline Type of Beams & Specimen's Labeling & Connector & Number of & \multicolumn{2}{l}{ Dimensions $(\mathrm{mm})$} & \\
& & & Specimens & Width & Depth & Length \\
\hline Control Beam & M1, M2, M3 & - & 3 & 45 & 90 & 1800 \\
Splice Beam & M4, M5, M6 & $20 \mathrm{~mm}$ dowel & 3 & 45 & 90 & 1800 \\
\hline
\end{tabular}

High strength threaded steel dowels of grade 8.8 were used. The bonded length, $\mathrm{L}_{\mathrm{b} \text {,min }}$ of steel dowel with $20 \mathrm{~mm}$ diameter is shown in Fig. 2. The bonded length was calculated according to the equation [1] as provided in Eurocode 5,

$$
L b, \min =\left\{0.4 d r^{2} \text { or } 8 d r\right\}
$$

where: $d r=$ diameter of rod.

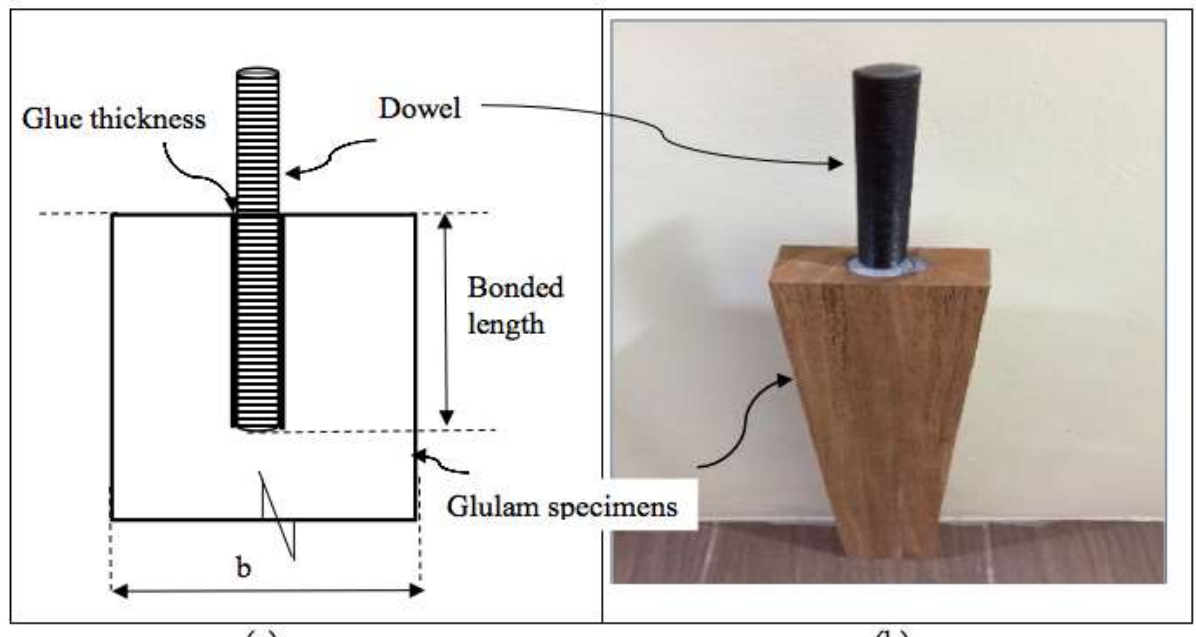

(a)

(b)

Fig 3: Cross-section of the Specimens: (a) Bonded length sketch-up of the specimen (b) Actual specimen 
The steel dowel act as connectors between the two members was inserted at each end of the glulam splice members. A hole was predrilled in each glulam specimen's end members prior to the dowel insertion. The hole size was pre-drilled with an extra allowable size which is within $3 \mathrm{~mm}$ diameter. The holes were drilled at $24 \mathrm{~mm}$ diameter with $160 \mathrm{~mm}$ embedded length of each.

Sikadur 30 (2-Component Epoxy Segmental Bridge Adhesive) Part A and Part B were used for glueing steel dowel to the glulam specimen. The mixing ratio is 3 teaspoons of Part $A$ to 1 teaspoon of Part $B$. The adhesive was poured into the hole before the steel dowel was inserted. The steel dowel was slowly inserted and rotated until it reached the embankment depth of the hole. By inserting the dowel slowly, the glue was pushed up, and in this particular method, the creation of air pockets was avoided. In order to achieve the full strength of the adhesive, the glued specimens were cured at least 10 days before testing.

The four-point bending test method, as shown in Fig. 3 was set up to test all specimens. The test apparatus, including load-bearing block, reaction bearing plate and roller support, were set up based on BS EN 408:2010. Lateral supports permitted the beam specimen to deflect without significant frictional resistance and prohibited buckling. The Linear Variable Displacement Transducer (LVDT) recorded the deflection readings. The bending strength, $f_{m}$ were calculated using the equation [2] as provided in BS EN 408:2010:

$$
f_{m}=3 F_{a} / b h^{2}
$$

where

$\mathrm{F}=$ load, $\mathrm{N}$

$\mathrm{a}=$ distance between a loading position and the nearest support in a bending test, $\mathrm{mm}$

$\mathrm{b}=$ width of a cross-section in a bending test, or the smaller dimension of the cross-section, $\mathrm{mm}$

$\mathrm{h}=$ depth of cross-section in a bending test, or the larger dimension of the cross-section, $\mathrm{mm}$

\subsection{Results And Discussion}

\subsection{Bending strength of the control and splice beams}

The maximum loadings for which the timbers were able to withstand were determined at the mid-span and the supports. The beam failure mode behaviour types that occurred during and after the bending test were observed and recorded. The result of bending maximum load, bending strength parallel to the grain, and displacement of the control and splice beam specimens are summarised in Table 2.

Table 2: Bending strength of the control and splice beams

\begin{tabular}{|c|c|c|c|c|c|c|}
\hline \multirow[t]{2}{*}{ Reference } & \multirow[t]{2}{*}{ Glulam Beam } & Sizes & $\begin{array}{l}\text { Maximum } \\
\text { Load }\end{array}$ & Displ. & Stiffness & $\begin{array}{c}\text { Bending } \\
\text { Strength Parallel to } \\
\text { grain }\end{array}$ \\
\hline & & $(\mathrm{mm})$ & $(\mathrm{kN})$ & $(\mathrm{mm})$ & $\mathrm{kN} / \mathrm{mm}$ & Mpa \\
\hline \multirow{8}{*}{ This study } & M1-Control & & 19.15 & 68 & 0.28 & 85.11 \\
\hline & M2-Control & & 25.03 & 105 & 0.24 & 111.24 \\
\hline & M3-Control & & 17.85 & 57 & 0.31 & 79.33 \\
\hline & Avg. & & 20.68 & 76.67 & 0.27 & 91.89 \\
\hline & M4-Splice & $45 \times 90 \times 1800$ & 5.88 & 36 & 0.16 & 26.13 \\
\hline & M5-Splice & & 4.91 & 28 & 0.18 & 21.82 \\
\hline & M6-Splice & & 5.23 & 32 & 0.16 & 23.24 \\
\hline & Avg. & & 5.34 & 32 & 0.17 & 23.73 \\
\hline Ismail et al. (2020) & $\begin{array}{c}\text { Mengkulang glulam } \\
\text { beam }\end{array}$ & $85 \times 90 \times 1710$ & 28.26 & - & & 81.3 \\
\hline
\end{tabular}

Comparisons of result for the control beam in this finding are also made to the result published by Ismail et al. (2020). It shows that the average load $(20.68 \mathrm{kN})$ and the bending strength capacity $(91.89 \mathrm{Mpa})$ performed in this study are acceptable and in the range of the previous results reported by Ismail et al. (2020) with a load $28.26 \mathrm{kN}$ and bending strength capacity of 81.30 Mpa respectively. Since the connection for this study was only jointed using a glued single $20 \mathrm{~mm}$ dowel, therefore these collected values are mainly the whole strength of the $20 \mathrm{~mm}$ dowel and adhesive capacity.

The stiffness of the splice beams was found to be reduced by $38 \%$ compared to the control beam. The stiffness of the control beam is expected to be higher because the fiber continuity in the tensile region remains intact with the glulam -compressed finger joint and glueline, compared to the connection at the splice end, which only held by a single glued bond of steel dowel. 
In comparison to bending strength parallel to the grain of MS544: part 2: 2001, the Mengkulang solid timber is stated between 6.8 to $12.1 \mathrm{~N} / \mathrm{mm} 2$ (wet and dry condition). Thus, based on the bending strength of the glulam, this study shows that the control and splice Mengkulang glulam is nearly 9 and 3 times higher than the strength of Mengkulang solid timber, respectively.

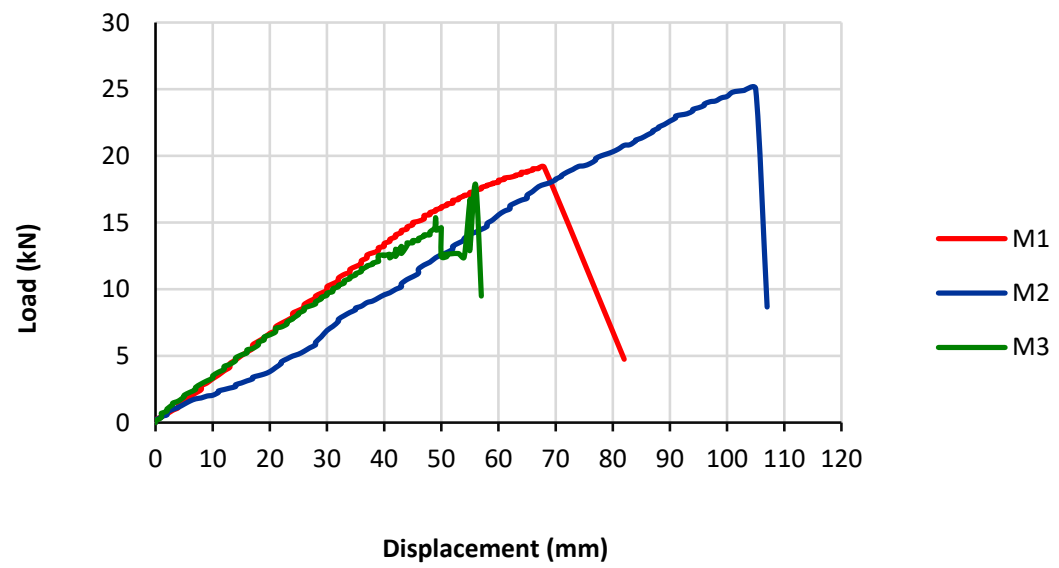

Fig.4: Load versus displacement of control beams

Fig. 4 shows that all three specimens failed in a brittle manner. The curves demonstrated load increases to a high loading point in a linear feature and followed by a sudden fracture which; signified that the specimens had reached their maximum load capacity. When the specimens reached their maximum bending strength and fully displaced at the mid-span, it ruptures without any sign of warning with a big audible crack. Among the three control specimens, M2 reached the highest maximum bending strength at $25.03 \mathrm{kN}$ with a corresponding $105 \mathrm{~mm}$ displacement at the mid-span.

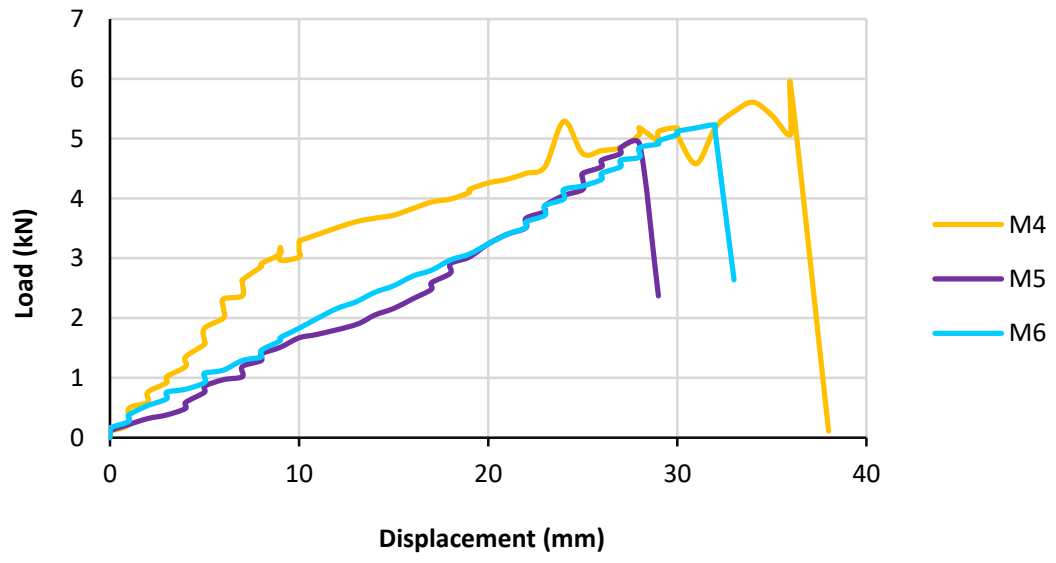

Fig.5: Load versus displacement for splice beams.

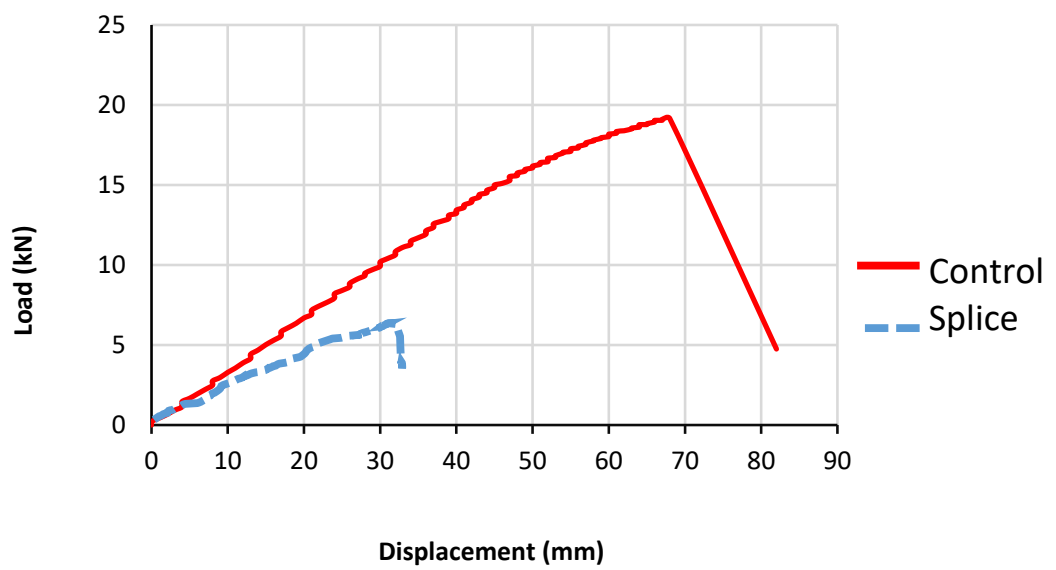

Fig. 6: Typical curves of load versus displacement for the control and splice beam 
Fig. 5 shows all the three specimens performed in a similar brittle manner which; replicates the control beams failure with linear features. During the fracture failure, the glulam beam specimen broke with a loud audible crack. Among the three specimens with steel dowel, M4 was able to reach the $5.88 \mathrm{kN}$ highest maximum bending strength, with $36 \mathrm{~mm}$ displacement at the mid-span, accordingly.

The following Fig. 6, shows the typical curves performance comparison between the splice and control beam. It shows the similar brittle pattern of behavior between the two types of beams. Typically the average load carrying capacity of the control beam is higher compared to the splice beam. Fig 7 and 8; are the percentage performance of the average bending strength and the displacement comparisons of the beams respectively.

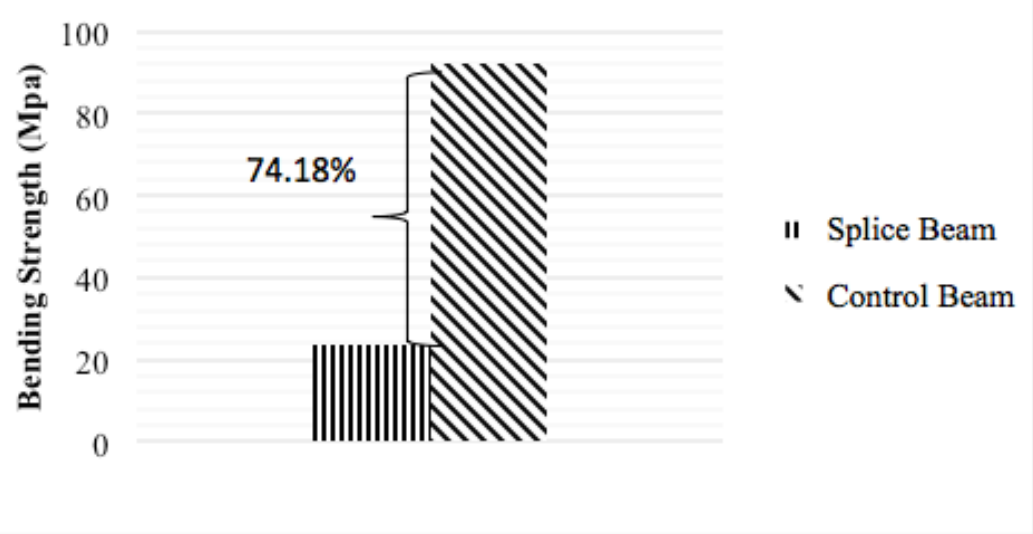

Fig. 7: Bending strength comparisons between control and splice beam

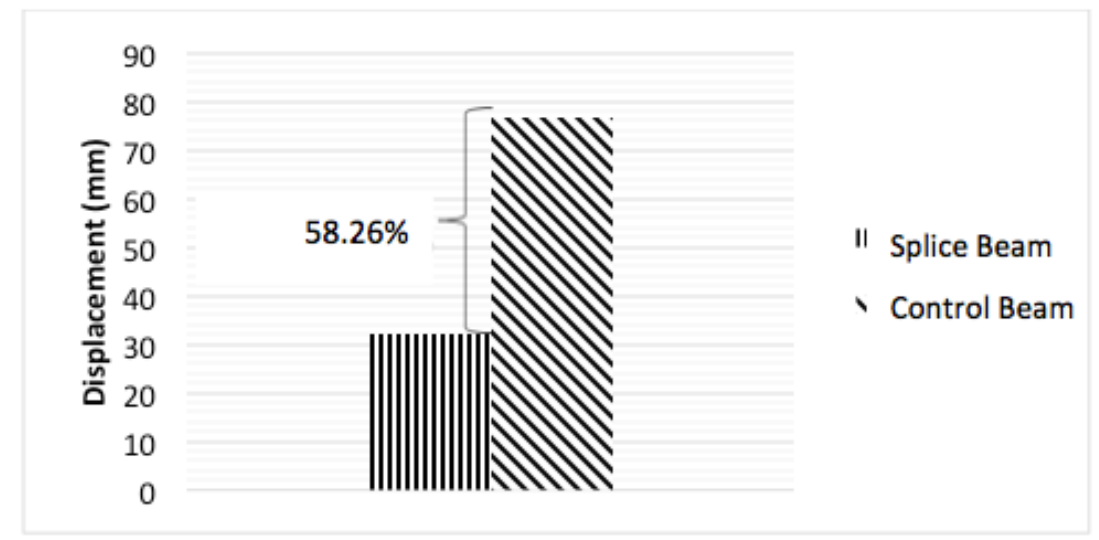

Fig. 8: Displacement comparisons between control and splice beam

\subsection{Types of Failure Modes}

The glulam beams showed typical bending failures. Brittle failure modes occur in both; the control beam and splice beam specimens. The initial failure occurred in the tension zone most often at or close to a finger-joint. The load was first dispersed on the surface of the specimen, near to the glued-in steel dowel prior to the appearance of the cracks and slowly propagated to the timber glue-lines (Fig. 9). On the other hand, the longitudinal cracks failure appeared in staggered at splice beam specimens. The fracture observed also indicated failure of the grain deviation due to stresses at the tension zone.s. These behaviours were as well supported through the load versus displacement pattern of failures as displayed in Fig. 4 and Fig. 5 previously.

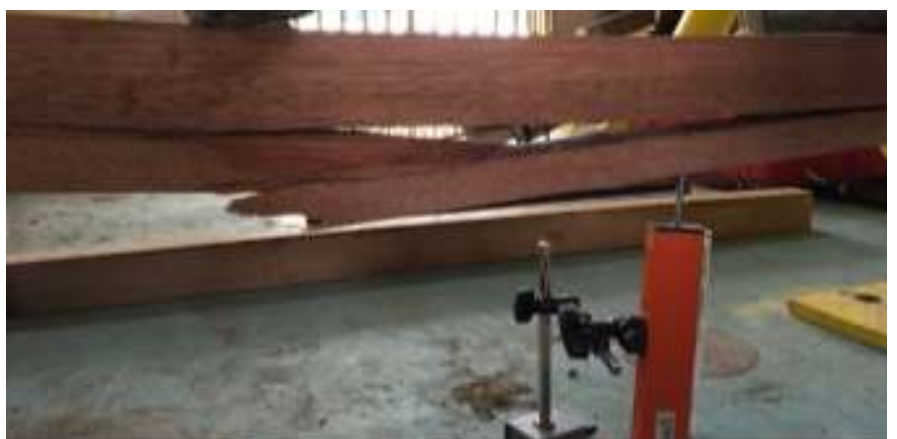

Fig 9: Failure of control beam specimens with large cracks at the middle of the beam. 


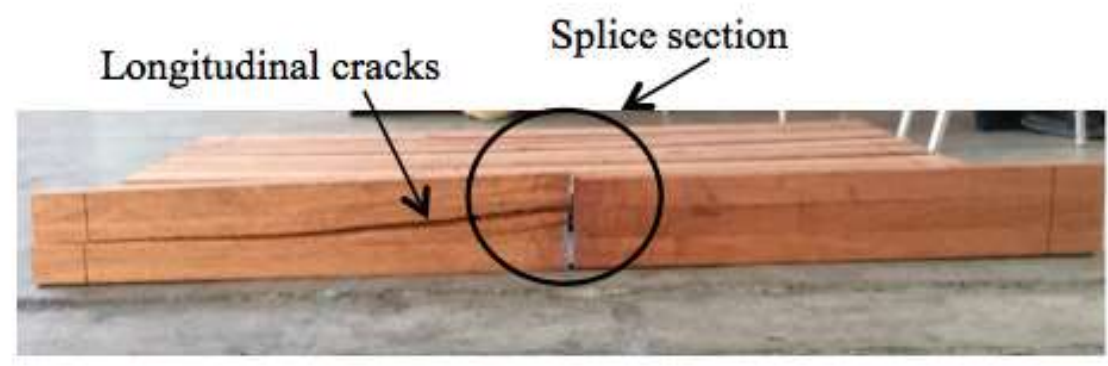

Fig 10: Failure of steel dowelled splice beam with longitudinal cracks at the splice ends.

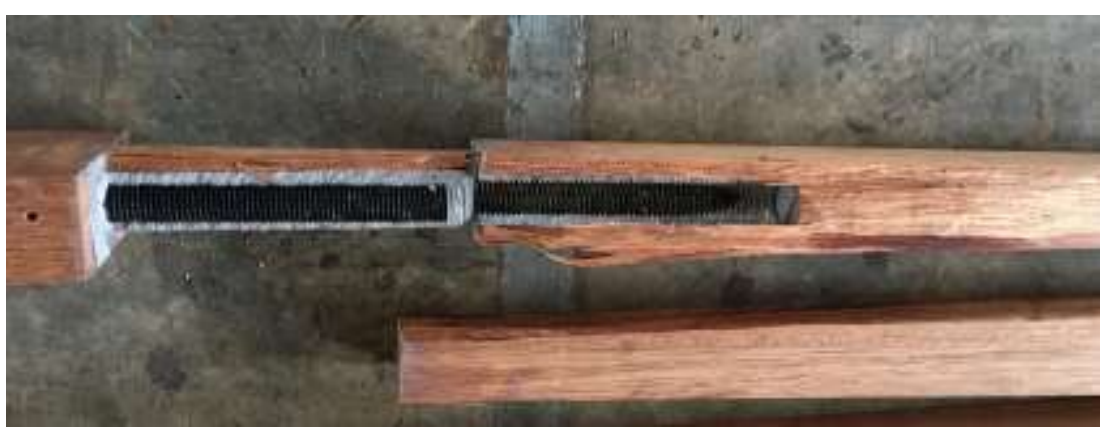

Fig. 11: Splitting of timber and glue failure at the dowel tension zone at splice ends connection.

The slight differences in failure modes performances and load-carrying capacity performance between the control and the splice joints were significantly observed and measured. The failure take place at the specimen M5 surface which near to the glued in steel dowel then the cracks slowly propagated to the timber glueline. In general, the initial crack was initiated at the extreme bottom fibre around the mid-span and followed by a fast crack growth due to brittle splitting. This result is in agreement with the previous findings as reported by Ismail et al. 2020, Anshari et al. (2010) and Zarnani, 2014 in their study.

The overall bending strength was found to be poor and far low compared to the control beams. The performances of the beams with splice joints failed earlier than the control beams. Once the maximum load was applied, timber began to bend at the splice connection, reacted on the moment rotation of the beam with brittle plug shear failure of the splice joints. Yet, the steel dowels still holding the beam in place without yielding. It shows that the failure was due to the splitting of timber and the $20 \mathrm{~mm}$ dowels shall resist the maximum load and stays intact. Fig. 11 shows the splitting of timber and glue failure at the dowel tension zone at splice ends connection after the test. The existence of splice in a beam was tremendously affected the whole beam strength by the brittle wood behaviour, steel dowel moment-resisting performances and load carrying capacity, accordingly. The ready cut-off splice joint and ductile behaviour of the dowels contributes to lesser cracks and splitting in splice beams compared to the control beams. The moment resisting is minimal in this study since the resistance is only held up by a single dowel.

\subsection{Conclusion and recommendation}

This paper presented research on the bending properties of control and splice connection Mengkulang glulam loaded parallel to the grain. The bending tests were carried out according to BS EN 408: 2010 to determine the load-carrying capacity and bending strength parallel to grain (i.e. modulus of rupture, $\mathrm{fm}$ ). From the three Mengkulang samples of control and splice glulam, the control Mengkulang glulam exhibited nearly 4 times the load-carrying capacity of a single dowelled spliced beam from the results of $20.68 \mathrm{kN}$ and $5.34 \mathrm{kN}$, respectively. While the control beam specimens performed $74.18 \%$ higher bending strength compared to glulam splice beam specimens. Both fail in a brittle manner due to tension failure but performed in different stages mode of failure.

Due to the absence of data for the delamination test of Mengkulang glulam, the bonding quality was not discussed in this research. Future research should emphasize testing the different diameters and increasing number of dowels and number of specimens to obtain sufficient and reliable data for subsequent development of characteristic strength of the glulam manufactured from tropical hardwood.

\section{Acknowledgements}

The work reported here was financially supported by the I-Geo Disaster Research Centre of the Infrastructure University Kuala Lumpur (IUKL), Kajang, Selangor Darul Ehsan. Amanda Law Siew Ling (IUKL student) is gratefully credited for her huge commitment in this project. The teamwork also comprises members from Segi University, Universiti Teknologi MARA and Universiti Putra Malaysia (UPM), respectively. 


\section{References}

Ahmad, Y. (2013). Ductility of Timber Beams Strengthened Using Fibre Reinforced Polymer. Journal of Civil Engineering and Architecture, ISSN 1934-7359,USA, Volume 7, 535-544

Anshari,B., Guan Z., Komatsu,K., Kitamori, A. and Kiho Jung, K., (2010). Explore Novel Ways to Strengthen Glulam Beams By Using Compressed Japanese Cedar. World Conference on Timber Engineering (WTCE), Lake Garda, Italy. ID. 365

BS EN 408:2010; Timber structures - Structural timber and glued laminated timber - Determination of some physical and mechanical properties

Ismail, S., Muhammad N.A and Ahmad, Z. (2020). Bending properties of Mengkulang Glued laminated (glulam) timber and laminated veneer lumber (LVL). International Journal of Basic \& Applied Sciences IJBAS-IJENS Vol:20 No:02 PP: 1-16

Kliger, I.R., Johansson, G., Perstorper, M. and Engström, D. (1994). Formulation of Requirements for the Quality of Wood Products Used by the Construction Industry. EEC Forest Project MA2B-0024 "Sil- vicultural Control and Non Destructive Assessment of Timber Quality in Plantation Grown Spruces and Douglas fir" Final Report on Task 12. Chalmers Uni- versity of Technology, Sweden, 63 pp.

MS 1714: 2003; Specification for Visual Strength Grading of Tropical Hardwood Timber.

MS 544: Part 2: 2001. Malaysian Standard. Code of Practice for Structural use of Timber. Department of Standards Malaysia. SIRIM.

MS 544: Part 3: 2001. Malaysian Standard. Code of Practice for Permissible Stress Design of Glued Laminated Timber. Department of Standards Malaysia. SIRIM.

MS 758: 2001; Glued Laminated Timber- Performance requirements and minimum production requirements.

Malaysian Timber Industry Board (MTIB), Johor, Malaysia. https://rotafix.co.uk/case-studies/mtib-glulam-frame/) Retrieved: 7 September 2021.

Margarita, A. (2017). Strength analysis of wooden curved beams. Thesis for Double Degree Programme in Civil and Construction Engineering. Saimaa University of Applied Science, Technology, Lappeenranta.

Malek, N.J.A, Hui, L. S. and Hassan, R. (2020). Performance of Withdrawal Capacity for Mengkulang Glulam Perpendicular to the Glue Line for $14 \mathrm{~mm}$ and $20 \mathrm{~mm}$ Bolt Diameter. International Journal of Innovative Technology and Exploring Engineering (IJITEE) ISSN: 22783075, Volume-9 Issue-3, January 2020

Malek, N.J.A., Hassan, R., Hussin, T.A.R., Tern, N.D., Adam, C. (2016). Perpendicular dowel-bearing strength properties without glue line for Mengkulang species. Journal of Mechanical Engineering 2016, 13(1), pp. 45-56

Malek, N.J.A., Hassan, R., Kamari, S.N.S.M., Shakimon, M.N., Long, C.Y. (2016). Performance comparison of bolt withdrawal capacity for mengkulang glulam. Journal of Mechanical Engineering 2016, 13(2), pp. 113-124

Malek, N.J.A, Al-Afif, A. A., Hassan, R. (2019). Shear Block Test Performance of Melunak and Mengkulang Parallel to Glueline. IOP Conference Series: Materials Science and Engineering 2019, 507(1), 012015

Mohamad, W.N.N., Suliman, N.H., Kamarudin, M.K., Mohd-Amin, N., Hassan, R. (2018). Pull-out strength of steel rods bonded into mengkulang (tarrietia javanica) glulam at five different angles to the grain. Journal of Tropical Forest Science 2018, 30(1), pp. 67-74

Moore, J.R., Mochan,S.J., Brüchert, F., Hapca, A.I., Ridley-Ellis,D.J., isępiGardiner, B., A., and Lee, S.J. (2009). Effects of genetics on the wood properties of Sitka Spruce growing in the UK: bending strength and stiffness of structural timber. Forestry, Vol. 82, No. 5, 2009. doi:10.1093/forestry/cpp018 Advance Access publication date 23 June 2009

Robot (2018). Structural Analysis Professional 2018. Hilfe Startseite.

Smith, I., Asiz, A., \& Snow, M. (2006). Design Method for Connections in Engineered Wood Structures. Published by Semantic Scholar. Corpus ID: 110195988.

G.N. 5178/1984. Uniform Building By-Laws 1984. Date of publication: 12th September 1985. Date of coming into operation: 13th September 1985.

Wan Mohamad, W., Razlan, M. A., \& Ahmad, Z. (2011). Bending strength properties of glued laminated timber from selected Malaysian hardwood timber. International Journal of Civil \& Environmental Engineering, 11(4), 7-12.

Zarnani, P. (2014). Design Method For Coupled-Splice Timber Moment Connections, (September). http://doi.org/10.13140/2.1.2664.8966 